\title{
Methodological Approach and Technological Framework to Produce a Massive Open Online Course (MOOC) in Biodegradable Packing*
}

\author{
Anabel Guzman Ordoñez ${ }^{* *}$ \\ Carlos León Casanova $a^{* * *}$ \\ Héctor Samuel Villada Castillo**** \\ Jhon Jairo Palechor Tróchez $z^{* * * * *}$ \\ Carlos León Roa ${ }^{* * * * *}$
}

Received: 26/10/2019. Accepted: 28/05/2020
https://doi.org/10.22395/rium.v20n38a13

\begin{abstract}
This article aims to present the differentdesign and production stages of a MOOC (Massive Open Online Course) for biodegradable packing and the planning tools and methodologies used for the development of the topics and contents. Likewise, it showed the technological framework used to make a surveillance technology to identify in which stage the MOOC e-learning tech is and how to search terms related to biodegradable packing to identify potential topics. Finally, due to the practice made, the software architecture for Selene (technology platform) is explained as well as how it is deployed in the open edX platform.
\end{abstract}

Keywords: e-learning; online education; learning systems; educational technology; content management; massive open online course; biodegradable packing.

Article derived from the Seminar in Educational Innovations - Sinnem18 (Seminario en Innovaciones Educativas) October 2018. MOOC MenTES-Project, University of Cauca.

** Ph.D. (c) in Business. University of Cauca, Popayan, Colombia. E-mail: anabelguzman@unicauca.edu.co. Orcid: https://orcid.org/0000-0002-4039-8450

*** Systems Engineer. University of Cauca, Popayan, Colombia. E-mail:Carleon1792@gmail.com

${ }^{* * * *} \mathrm{Ph}$.D. in Engineering with an emphasis in Food Engineering. Cytbia research group. University of Cauca, Popayan, Colombia. E-mail: villada@unicauca.edu.co. Orcid: https://orcid.org/0000-0002-5557-3215

****** Master in Agro-industrial Engineering. Cytbia research group. University of Cauca, Popayan, Colombia. E-mail: jjpalechor@unicauca.edu.co. Orcid: https://orcid.org/0000-0003-4756-2812

${ }^{* * * * * *}$ MBA, Ph.D. (C). Cytbia research group. University of Cauca, Popayan, Colombia. E-mail: cleon@unicauca. edu.co. Orcid: https://orcid.org/0000-0002-1791-2693 


\title{
Enfoque metodológico y marco tecnológico para producir un Curso Masivo Abierto Online (MOOC) en empaques biodegradables
}

\begin{abstract}
Resumen
Este artículo tiene como objetivo presentar las distintas etapas utilizadas para el diseño y la producción de un MOOC para empaques biodegradables y las herramientas de planificación y metodologías utilizadas para el desarrollo de los temas y contenidos. Del mismo modo, se muestra el marco tecnológico utilizado realizando la vigilancia necesaria para identificar en qué etapa está la tecnología de e-learning MOOC y la búsqueda de términos relacionados con "biodegradable packing" para identificar temas potenciales. Por último, se explica la arquitectura de software para Selene (Plataforma tecnológica) y cómo se implementa en la plataforma Open edX.

Palabras clave: aprendizaje electrónico; educación online; sistemas de aprendizaje; tecnología educativa; gestión de contenidos; curso masivo en línea abierto; embalaje biodegradable.
\end{abstract}




\section{INTRODUCTION}

Online education has taken a significant resonance due to the use of information technologies that help in the learning process and shorten the gap between the student and educational institutions or experts in different areas of knowledge, while generating a fast and updated information flow, as well asdisruptive education models [1].

A MOOC (Massive Open Online Course) provides agile and open-knowledge tools, allowing thousands of people to access training and improve their professional skills or educate themselves on topics of interestwithout restriction [2]. Being open and online courses, the platforms allow free access just under a simple registration, and the user can access any resource. Besides, the user can enrol in courses anywhere globally and do training in real-time with students from different countries. The platforms used the most by Higher Education Institutions (HEI) to publish a MOOC are EdX, Coursera, MiríadaX, and Udacity. Based on a connective approach, these platforms make the individual independent of choosing what to learn [3]. These platforms support the courses' contents and guarantee reliability and quality. The platform used for the University of Cauca is Selene, supported by Open edX, and itsopen source, allowing that the development and design is adjusted to each one of the MOOCs. The system is divided into two main parts. Open edX Studio for teachers who wish to create courses for the platform and, on the other hand, open edX LMS (Learning Management System), the Learning Management System, focused on students who consume the courses. The content that can be integrated into a course is multimedia and supports various formats, such as books or videos, adapted to current learning needs. It also has integrations with social networks, discussion forums, and consultation of doubts where, both students and teachers, can participate. It allows the teacher to communicate with the students and control their progress in the course [4].

In the last years, many universities and schools faced adopting online educational models to meet the needs of students and workers. This change is revolutionary because, to develop this content, we need to bring together content experts, instructional designers, technology experts and experts in audio-visual materials. The data recorded for 2019 shows the great potential and reception the MOOCs have had. Of all the students registeredat the moment in MOOC platforms, one third did so in 2020 [5]. MOOC's large suppliers grew in 2020, and it is estimated that there are approximately 180 million students globally, 60 million more than those registered in 2019, excluding China. Data from Class Central [5] shows that providers launched more than 2800 courses, 360 microcredits, and 19 online degrees, with a record of approximately 950 universities certified. 
Hence, this document aims to present a methodology and frameworks used for creating and producing a MOOC. Primary concepts about biodegradable packing, a trending topic identified after the surveillance technology, identify the cycle of life for the e-learning technology and the courses' thematic. The technological surveillance process served to identify the MOOC stage as an e-learning solution and gave a broadthematic aspect to explore for future courses.

\section{METHODOLOGICAL APPROACH CREATING AND PRODUCING A MASSIVE OPEN ONLINE COURSE (MOOC)}

The methodology used for the creation and production of MOOC in biodegradable packaging was based on a canvas model, the same used for business models, which through a technology transfer process with the University Carlos III of Madrid carried out several pieces of training for the adoption and use of this type of methodology to the construction of the MOOC [6]. Likewise, for the generation of topics related to biodegradable packaging, a matrix was made where it was possible to show relevant contents and then cross them to produce more thematic fields.

\subsection{MOOC features and $\mathrm{MOOC}$ canvas model}

The MOOC Canvas is a conceptual tool that provides the description and design for MOOCs. The same structure of the CanvasBusiness Model is used, which is a model for generating business ideas and organizational resources [6]. This model has 11 boxes with a description of the available resources (human, intellectual, equipment and available technologies) and an overview of the course (description, target audience, pedagogy, learning objectives, evaluation, and complementary technologies) [7].

The MOOC Canvas created for the Biodegradable Packaging course in figure 1 shows the available resources, the human capital, production and design technicians, MOOC MenTES project managers, recording equipment and visual material [8]. 


\begin{tabular}{|c|c|c|c|c|c|}
\hline \multicolumn{2}{|c|}{$\begin{array}{l}\text { 1. Human } \\
1.1 \text { Expert } 1=2 \text { weekly hours } s * 10 \text { weeks }=20 \mathrm{H} \\
\text { Expert } 2=2 \text { weekly hours } * 10 \text { weeks }=2 \mathrm{OH} \\
\text { Expert } 3=2 \text { weekly hours } * 10 \text { weeks }=2 \mathrm{H} \\
\text { Approximately there is a total of } 60 \text { hours of availability for } \\
\text { the design and production phases }\end{array}$} & \multicolumn{3}{|c|}{$\begin{array}{l}\text { 2. Intellectual } \\
2.1 \text { Cytbia research group has enough material } \\
\text { and information (PHOTOS, videos, learning } \\
\text { material) that will help in the course } \\
\text { development. }\end{array}$} & $\begin{array}{l}\text { 3. Equipment } \\
\text { 3.1 The resources that have hardware and software } \\
\text { are supported by the technical and creative team of } \\
\text { the project, who will provide support in the } \\
\text { audiovisual and technical production of the MOOC. }\end{array}$ \\
\hline \multirow{5}{*}{$\begin{array}{l}\text { 4. Platform } \\
\text { Selene is the platform where will } \\
\text { be located all the MOOC content } \\
\text { for Biodegradables Packing } \\
\text { 4.1 The formats supported by the } \\
\text { platform are video, images, text } \\
\text { and audio }\end{array}$} & \multicolumn{5}{|c|}{$\begin{array}{l}\text { 5. General Description } \\
\text { 5.1. Introduction to Biodegradable Packing } \\
\text { 5.2 Duration : } 4 \text { weeks }\end{array}$} \\
\hline & \multicolumn{5}{|c|}{$\begin{array}{l}\text { 6. Target learners } \\
\text { 6.1 People in Colombia who do not have a clear concept on biodegradable packaging and want to better understand its definition, typology, } \\
\text { materials for production and regulations.: High school students, first semesters of agribusiness and leaders of Agricultural production associations. }\end{array}$} \\
\hline & \multicolumn{3}{|c|}{$\begin{array}{l}\text { 7. Pedagogical approaches } \\
7.1 \text { Knowledge transfer. }\end{array}$} & \multicolumn{2}{|c|}{$\begin{array}{l}\text { 8. Objectives and competences } \\
8.1 \text { To know concepts, to understand typology, to identify raw } \\
\text { materials, to know biodegradable packaging regulations. }\end{array}$} \\
\hline & \multicolumn{3}{|c|}{$\begin{array}{l}\text { 9. Learning contents } \\
\text { 9.15 modules } 1 \text { introduction, } 4 \text { content course) } \\
9.2 \text { Format: vides, , ddfs, docs, ppts, uRL extra. } \\
9.3 \text { The platforma does not allow allocated videos, those are saved in YouTube }\end{array}$} & \multicolumn{2}{|c|}{$\begin{array}{l}\text { 10. Assessment activities } \\
\text { 10.1 Multiple selection test at the end of each section. } \\
\text { 10.2 Only one multiple response test is contemplated } \\
\text { 10.3 The platform support all the activities }\end{array}$} \\
\hline & \multicolumn{5}{|c|}{$\begin{array}{l}\text { 11. Complementary technologies } \\
11.1 \text { YouTube to allocate videos with caption } \quad 11.3 \text { Facebook } \\
11.2 \text { No apply }\end{array}$} \\
\hline
\end{tabular}

Figure 1. MOOC Canvas model for biodegradable packing course Source: 0 wn elaboration.

\subsection{Design process for a MOOC}

Once the canvas model was created, the idea and conception to design a MOOC went through different stages in which the creative and technical team developed a final product. Initially, a matrix was made to generate potential subjects the MOOC could take; once the thematic was chosen, which in this case was an essential aspect of Biodegradable Packing andwas focused on specific topics: it was necessary to perform a process of technological surveillance tochoose the main title and the potential contents.

The matrix is developed to generate ideas for possible themes that can be addressed in the MOOC. The matrix works by crossing ideas about agro-industry issues. Fourthematic groupswere defined: biodegradable packaging; packing using cassava; packing using sisal; biodegradable materials. After that, they were crossed between each other for acquiring ideas for a possible MOOC. These four themes were selected because of the relationship between each one of them, a product theme that has biodegradable packaging with two raw materials with which they are produced and another theme of biodegradable materials in general, using the same raw materials. Afterwards, it presents a matrix for generating MOOC ideas in the agro-industry components. 


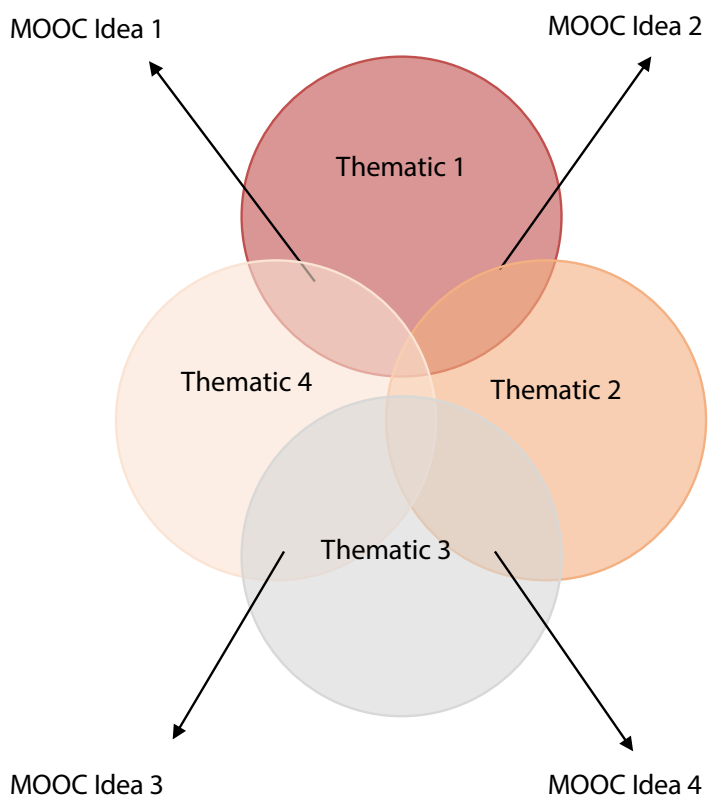

Figure 2. Matrix for ideas generation of $\mathrm{MOOC}$ courses Source: Own elaboration.

Then, a brainstorming was performed with the experts and researchers of the Cytbia (Ciencia y Tecnología de Biomoléculas de Interés Agroindustrial) research group, which made their proposals and gave guidelines for managing concepts and ideas. The matrix generated more than 19 potential ideas for courses which primary goal was being an attractive thematic to be easily massified, following, thus, one of the principal characteristics of the MOOCs [9].

After producing the matrix, the researchers gave their proposals for the contents that can be developed, and the introductory course on biodegradable packaging was created. That course will be the first course of four to come, which will have more in-depth content with topics like biodegradable and compostable materials and other raw materials used such as yam, plantain, sweet potato, arracacha, sour cassava andindustries' waste.

\section{TECHNOLOGICAL FRAMEWORK TO PRODUCE A MASSIVE OPEN ONLINE COURSE (MOOC)}

\subsection{S-curve for lifecycle of a $\mathrm{MOOC}$ technology and technological surveillance}

The systematic process of technological surveillance consists of collecting, analyzing, and disseminating information, whether in economic, technological, political, social, 
or other areas to identify opportunities and threats for improving the formulation and implementation of the strategy in the organizations [10].

Furthermore, the Spanish Association of Standardization [11] affirms that technological surveillance is an organized, selective, and permanent process to capture information from abroad and from the organization itself on science and technology. This data collection is selected, analyzed and disseminated to turn it into knowledge, takelesser risky decisions and anticipate changes.

This capture, analysis, dissemination and exploitation of technical information is useful for permanence and growth, whether it be for a university or a company. The search for background in articles and patent databases facilitates the detection of emerging technologies,innovations and the evolution of technologies that arouse particular interest in a specific field selected [12].

\subsubsection{S-curves for technology life cycle analysis}

The S-curve or analysis of the life cycle of technology is of great importance in technological vigilance studies to identify the state of development of technology. Studies related to S-curves' employment identify different stages or phases delimited by specific points in their growth [13-14].

As shown in (1) and table 1 were used to create a sigmoidal model with a significant difference less than 0.05 , indicating that the behaviour of documents published for the $M O O C$ keyword performs an exponential growth characteristic of S-curves, perceiving that this theme is in its globalization stage and gaining virtual spaces in the training processes.

$$
f=\frac{a}{1+e^{\frac{-\left(x-x_{0}\right)}{b}}}
$$

Table 1. Statistical analysis for the sigmoidal model and the keyword MOOC for each coefficient of equation 1

\begin{tabular}{llllc}
\hline & Coefficient & Std. Error & \multicolumn{1}{c}{$\mathbf{t}$} & \multicolumn{1}{c}{$\mathbf{P}$} \\
\hline a & 4307.5921 & 187.4140 & 22.9844 & $<0.0001$ \\
b & 1.1812 & 0.1026 & 11.5107 & $<0.0001$ \\
x0 & 2016.0209 & 0.1351 & 14926.5034 & $<0.0001$ \\
y0 & -24.5760 & 44.3062 & -0.5547 & 0.5926 \\
\hline
\end{tabular}

Source: Own elaboration. 


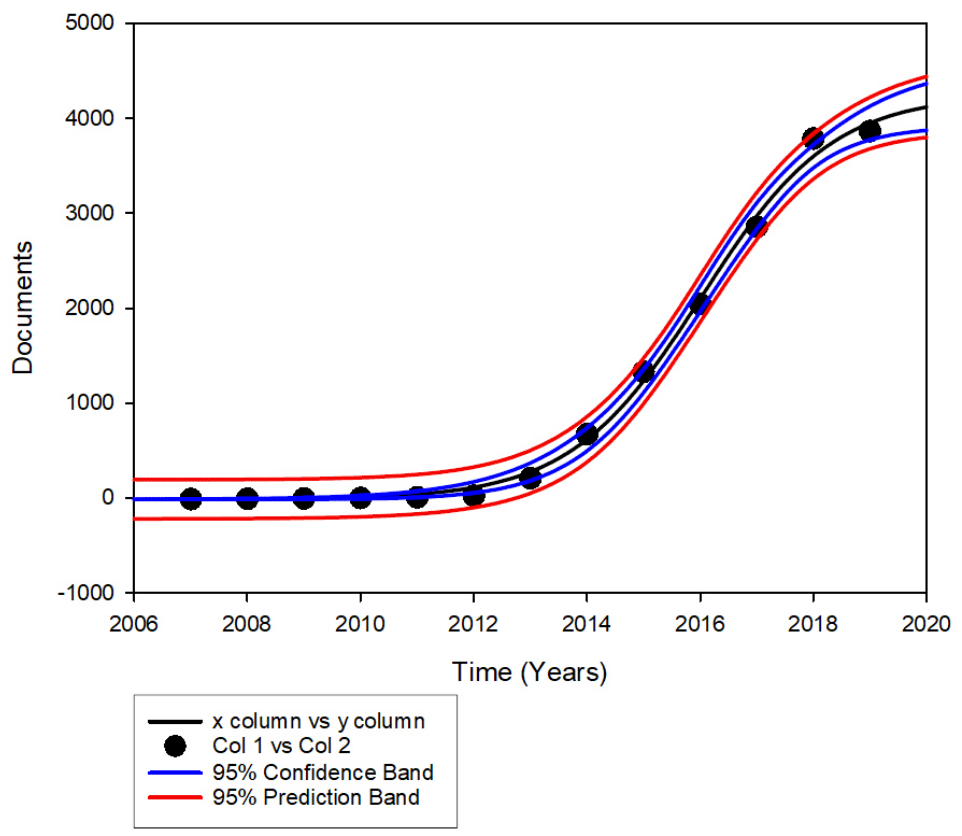

Figure 3. S-curve for MOOC technology stage

Source: Own elaboration.

Figure 3 proves the stage on the technology used by creating MOOC, which is increasingly mature into the life cycle exposed in the S-curve model.

Table 2. Data collected from the Metasearch engine SCOPUS using the MOOC keyword

\begin{tabular}{cc}
\hline Year & Accumulate \\
\hline 2007 & 2 \\
2008 & 5 \\
2009 & 9 \\
2010 & 13 \\
2011 & 21 \\
2012 & 37 \\
2013 & 221 \\
2014 & 685 \\
2015 & 1341 \\
2016 & 2052 \\
2017 & 2866 \\
2018 & 3794 \\
2019 & 3873 \\
\hline
\end{tabular}

Source: Own elaboration. 
Under the sigmoidal model, using the software SIgmaPlot (in trial version) a $\mathrm{R}$ equivalent to 0.9984 and an adjusted $\mathrm{R}$ of 0.9966 were obtained with a significant difference of fewer than 0.05 coefficients of the equation. In figure 3 , we observe the thematic behaviour concerning the MOOC, observing an upward tendency of MOOCs from 2006 to the date; the S-curve indicates that it is a technology on the rise. Below are the graphics obtained by SCOPUS using the keyword MOOC.

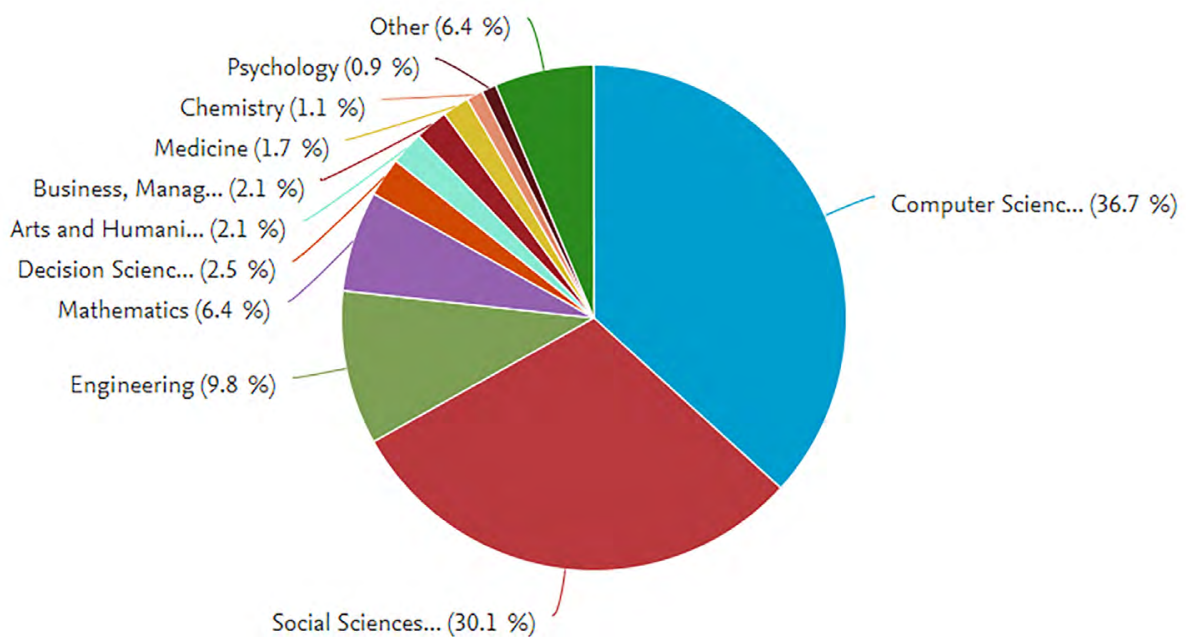

Figure 4. Documents found by area of study

Source: Own elaboration.

Figure 4 shows the most common study areas found in the $M O O C$ search: Computer science was the most popular (36.7\%), followed by Social science with $30.1 \%$ and Engineering in the third place with $9.8 \%$.

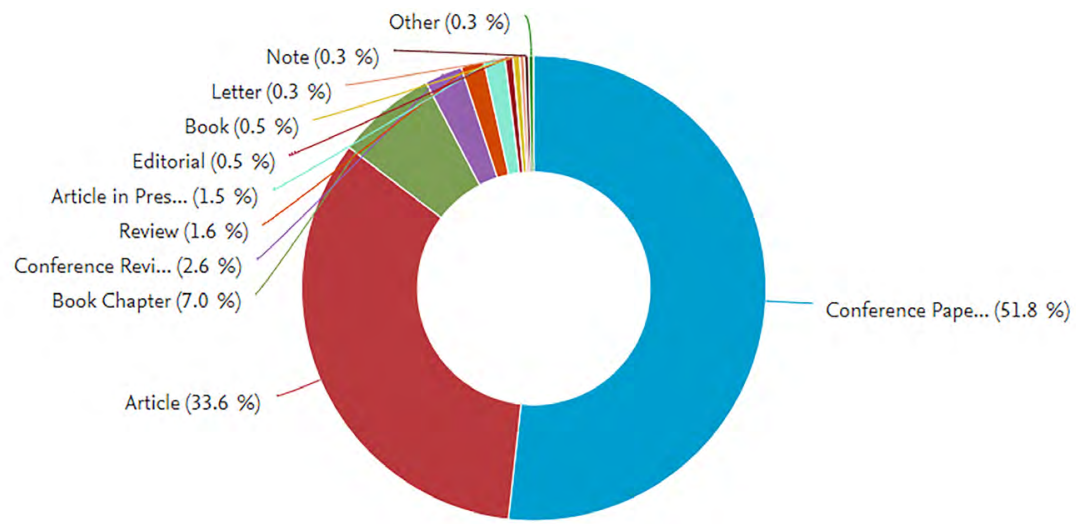

Figure 5. Documents found by type

Source: Own elaboration. 
The most common type of content found in MOOCs literature was conference papers $(51.8 \%)$, followed by articles (33.6 \%) and book chapters $(7 \%)$. There is an increase in the presentation of topics at academic events concerning MOOCs' development as a tool for learning and adopting new technologies focused on education.

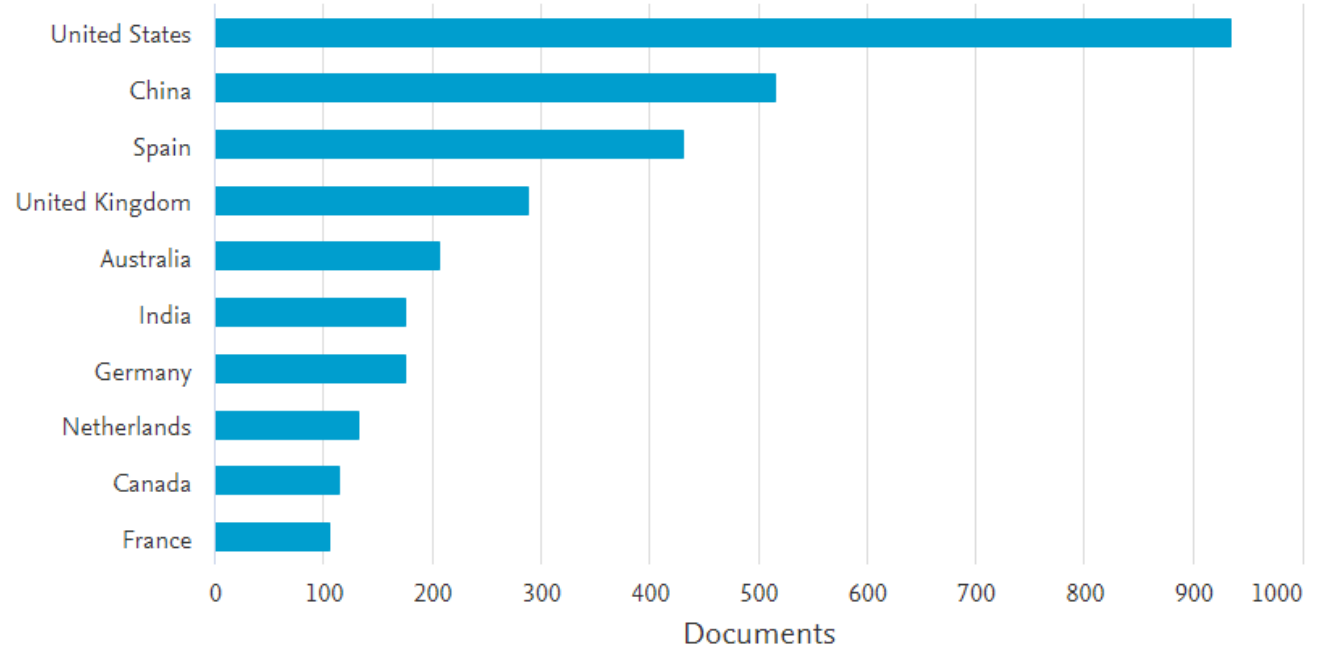

Figure 6. Documents found by country or territory Source: Own elaboration.

The United States (940) is the country with the highest rate of creating and producing MOOCs, followed by China (520), Spain (420) and the United Kingdom (290). Data from Latin-American countries is not recorded. It is an opportunity to improve educational practices by using new educational models that aid in the massification of comprehension and that limit the gap between more vulnerable communities in developing countries.

\subsubsection{Technological surveillance for content and structure used for MOOCs related to biodegradable packing}

In the management of emerging technologies and innovative educational models, it will be essential to perform searches that reference how the industry, the market, or, in this case, the educational programs are through MOOCs. Technological vigilance is an organized, selective, and permanent process where information about the technologies used and innovation levels are given. It is possible to anticipate changes and take decisions to reduce risks. For this reason, a short process of technological surveillance was carried out to identify the content and thematic for MOOCs in biodegradable packaging 
The platforms used and already mentioned for the search were EdX, Udemy, and Coursera, which used Spanish and English keywords related to biodegradation, biodegradable, and ecology, among others.

The search showed no MOOC topic about biodegradable packaging and biodegradation, representing training opportunities for thousands of people around the world and specifically in the rural population,which is the main goal. In the second stage of technological surveillance, structures and types of introductory contents used in similar courses were searched. The results are presented in the table below.

Table 3. Structure of MOOCs in biodegradable packaging searched

in MOOC platforms like open edX, Coursera, Udemy, etc.

\begin{tabular}{|c|c|}
\hline MOOC identified & Structure used for the introduction and $\mathrm{MOOC}$ presentation \\
\hline Industrial Biotechnology & $\begin{array}{l}\text { - Video intro } \\
\text { https://youtu.be/z11JTrml41Q } \\
\text { https://www.coursera.org/lecture/industrial-biotech/welcome-toindustrial-biotechnology-3XaFs } \\
\text { - About this course: A brief description of the course where a problem arises and how the course } \\
\text { solves this. } \\
\text { - Learning objectives } \\
\text { - Content } \\
\text { - Experts and professors responsible for the course }\end{array}$ \\
\hline $\begin{array}{l}\text { Introduction to water } \\
\text { and climate }\end{array}$ & $\begin{array}{l}\text { - Video intro } \\
\text { https://www.youtube.com/watch?v=dJEhwq0sXiQ\#action=share } \\
\text { - About the MOOC } \\
\text { - Content } \\
\text { - Experts and professors responsible for the course }\end{array}$ \\
\hline $\begin{array}{l}\text { Conventional, clean } \\
\text { energies and their } \\
\text { technology }\end{array}$ & $\begin{array}{l}\text { - Video intro } \\
\text { https://www.youtube.com/watch?v=JK5zoKpK1Hw\&feature=youtu.be } \\
\text { - About this course } \\
\text { - Learning objectives } \\
\text { - Experts and professors responsible for the course }\end{array}$ \\
\hline
\end{tabular}

Source: Own elaboration.

As a result of the search process, the courses' main sections were taken as a reference, and the introductory MOOC's structure in biodegradable packaging was defined. It included an introductory video where the expert and responsible for the course gives the initial characteristics, talks about the course's methodology and, finally, makes an invitation to register for the course. As part of the writing, a section is a detailed description of the contents, the learning objectives, the developed competencies, the length and who are the experts involved in the MOOC. 


\section{MOOC STRUCTURE IN SELENE PLATFORM FROM THE UNIVERSITY OF CAUCA}

A series of stages were performed to carry out the MOOC structuring process within the Selene platform of the University of Cauca, the following is a global description of each one. First, platform access must be managed to have a course administrator role to manage the content and achieve a more hands-on course structure edit. It is possible to create written resources within the platform, upload audio-visual material, share content from other platforms such as YouTube or some specialized blog, and generate evaluation material for the users who are taking the courses.

After getting access as manager, second stage starts with the establishment of the sections, subsections and configuration of the MOOC content. Similarly, the configuration of the tools applied for the course are created to make the content as interactiveand engaging as possible for the students. This process map shows the stages described above for the MOOC configuration into the Selene platform.

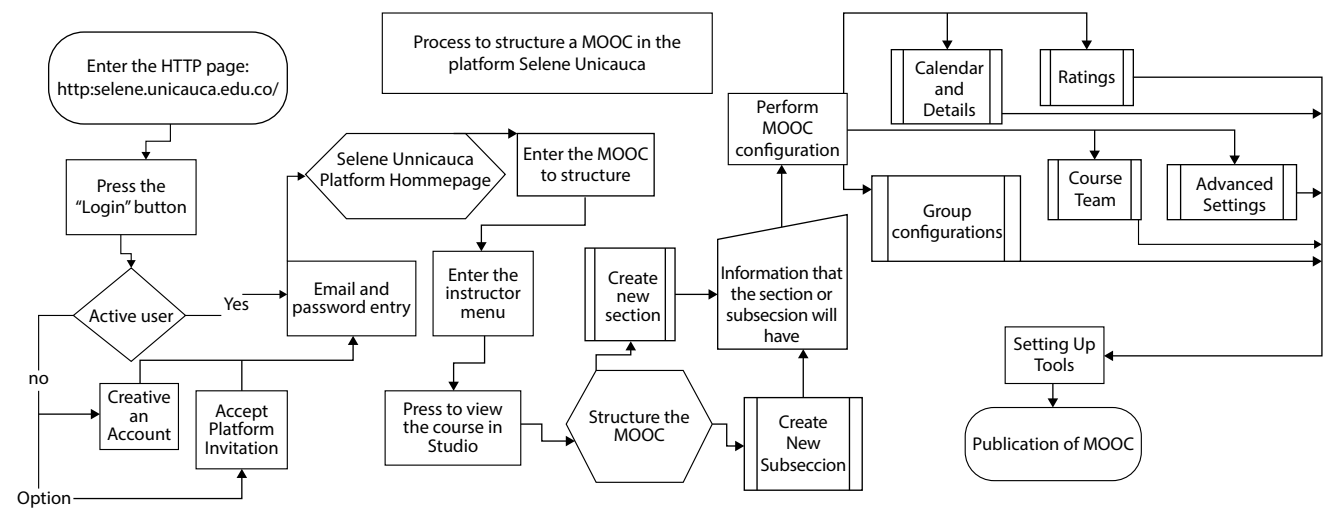

Figure 7. Process map to create the structure of MOOC in Selene platform from the University of Cauca

Source: Own elaboration.

\subsection{Software architecture for the Selene- edX platform}

Below is the detailed diagram of the Open EdX platform's architecture, a platform that supports Selene. This diagram shows the components and technologies used for their construction [15]. This platform is built mainly using the Django framework to develop web applications using the Python language. Besides, it uses other technologies that allow the platform to be deployed in most cloud providers or on-premises, facilitating its use and installation. 


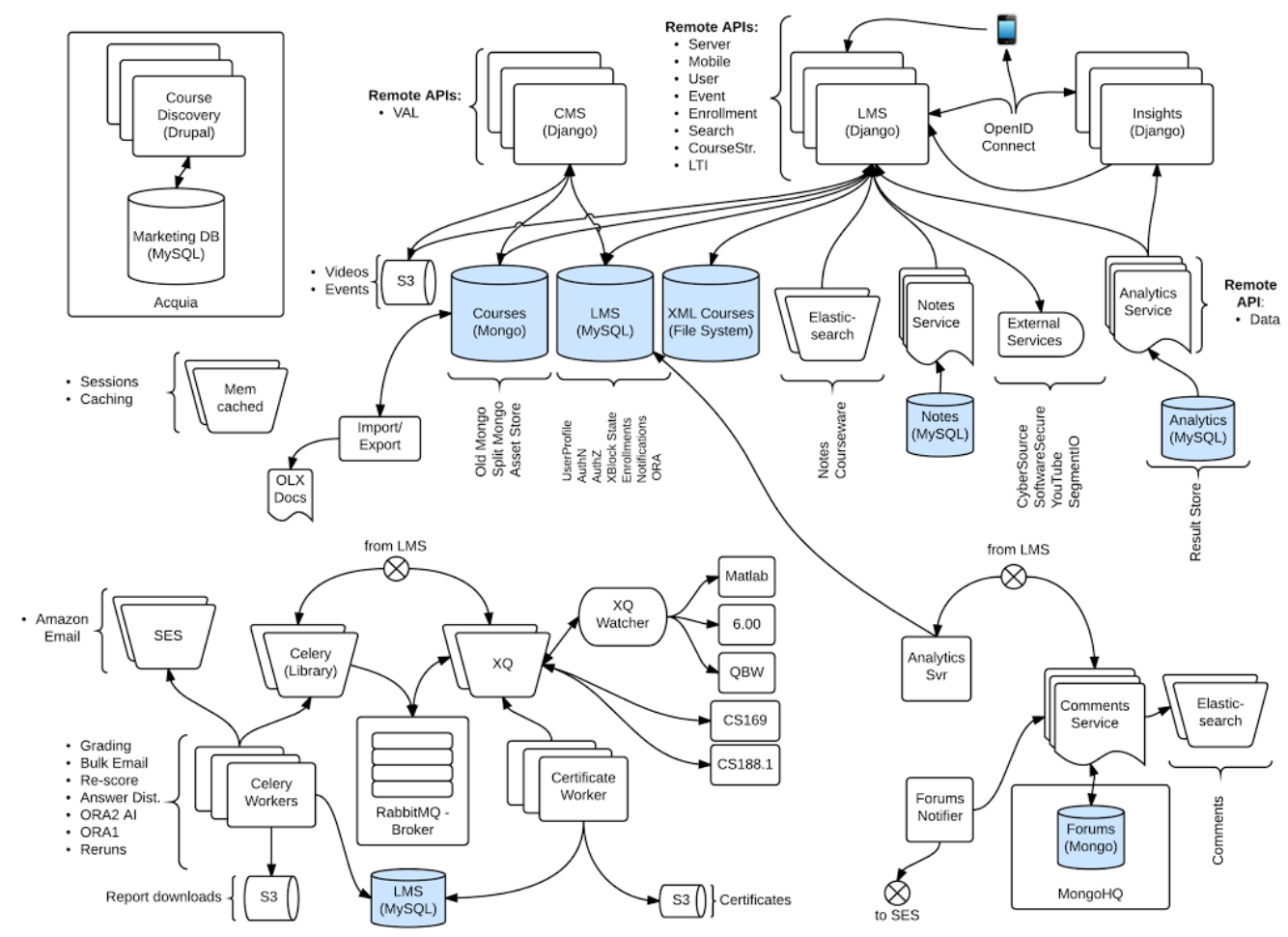

Figure 7. Software architecture diagram for Open edX

Source: Own elaboration.

Open EdX offers many features: the ability to show recorded lessons in a video with subtitles and indexing on the subtitles themselves (search by words that appear in them). When it clicks on the results, go directly to the video section that contains them. It is possible to add study materials (organized as books, notes or simple files) with different tests. It also has a virtual laboratory with an interactive interface (for electronics problems). As well as a calendar/course planner and multi-language support [15].

Within the platform, you can create discussion forums, wikis, and progress reports, which is a system to implement learning analytics. Also, there are various types of assignments: peer evaluation, self-assessment, hetero-evaluation, automatic evaluation, email event notification system, certificate issuance and integration with Google Hangouts. 


\section{CONCLUSION}

The MOOCs have powerfully impacted higher education and constitute one of the latest innovations that aim at lifelong learning for anyone motivated to continue training. This model made student schedules and work rates more flexible, as well as the advantage of having substantially more interactive material generating better engagement for students and reducing school drop rates. Increased outreach to more people interested in learning from particular topics changed the educational model, where geographic barriers do not impede further learning.

This paper aimed to give some highlights to create a MOOC using different approaches. The methodology approach exposed makes evident that creating and producing MOOCs can be carried out under planning tools such as the MOOC Canvas, which helps to overview all the resources needed to run the project. This model considers both physical resources and human resources and characterizes the course. Using a matrix that helped in the generation of thematic shortened the time and could be discussed further with the research group subjects within reach.

On the other hand, the technological surveillance process helped to measure the competitiveness of the technology and the previously generated themes. As a result, it showed great potential in the use of massive courses because it is a technology in a stage of maturity, as shown in the S-curve. Likewise, this study helped to identify types of content for production of the course, being the video and the article the most used in MOOC sources. In this way, taking into account the methodology and the technological framework, the MOOC's deployment was carried out in biodegradable packages in the Selene platform.

\section{REFERENCES}

[1] C. Alario-Hoyos, M. Pérez-Sanagustín, C. Delgado-Kloos, H. Parada G, M. MuñozOrganero and A. Rodríguez-de-las-Heras, "Analysing the Impact of Built-In and External Social Tools in a MOOC on Educational Technologies", Lecture Notes in Computer Science - Springer, 2013. Available: https://doi.org/10.1007/978-3-642-40814-4_2 [Accessed 20th November 2018].

[2] U. Nebrija, Metodología de enseñanza y para el aprendizaje Global Campus Nebrija. [E-book] Available:https://www.nebrija.com/nebrija-global-campus/pdf/metodologia-GCN.pdf, 2016.

[3] J. G. S. Goldie, Connectivism: A knowledge learning theory for the digital age?Med. Teach.,

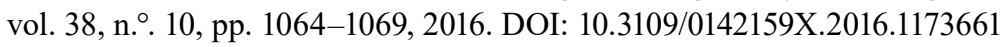

[4] J. A. Ruipérez-Valiente, P. J. Muñoz-Merino, H. J. Pijeira Díaz, J. S. Ruiz, and C. D. Kloos, "Evaluation of a learning analytics application for open edX platform," Comput. Sci. Inf. Syst., vol. 14, n. ${ }^{\circ}$ 1, pp. 51-73, 2017. Doi: 10.2298/CSIS160331043R 
[5] D.Shah., "By The Numbers: MOOCs in 2019”. Class Central [Online]. Available: https:// www.classcentral.com/report/mooc-stats-2019/

[6] C. Alario-Hoyos, M. Pérez-Sanagustín, C. Delgado-Kloos, H. Parada G, M. MuñozOrganero and A. Rodríguez-de-las-Heras, "Analysing the Impact of Built-In and External Social Tools in a MOOC on Educational Technologies", Lecture Notes in Computer Science - Springer, 2013. Available: https://doi.org/10.1007/978-3-642-40814-4_2 [Accessed 20th November 2018].

[7] C. Alario-Hoyos, M. Pérez-Sanagustín, D. Cormier, and C. Delgado-Kloos, "Proposal for a conceptual framework for educators to describe and design MOOCs," J. Univers. Comput. Sci., vol. 20, n. ${ }^{\circ}$ 1, pp. 6-23, 2014. DOI: 10.3217/jucs-020-01-0006

[8] C. Alario-Hoyos, M. Pérez-Sanagustín, C. Delgado-Kloos, H. Parada G, M. Muñoz-Organero and A. Rodríguez-de-las-Heras, "Analysing the Impact of Built-In and External Social Tools in a MOOC on Educational Technologies", Lecture Notes in Computer Science - Springer, 2013. Available: https://doi.org/10.1007/978-3-642-40814-4_2 [Accessed 20th November 2018].

[9] J. Knox, "Digital culture clash: 'massive' education in the E-learning and Digital Cultures MOOC”, Distance Educ., vol. 35, n. ㄹ, pp. 164-177, 2014. DOI: 10.1080/01587919.2014.917704

[10] M. I. Ramírez, D. Escobar Rua, and B. Arango Alzate, "Vigilancia Tecnológica E Inteligencia Competitiva," Rev. Electrónica Gestión las Pers. y Tecnol., vol. 5, n. 13, Feb. 2012, [Online]. Available: https://www.redalyc.org/articulo.oa?id=477847114018.

[11] J. C. Alustiza Aldasoro, M. L. JorduCantonnet Jordi, and E. Carrasco Cilleruelo, "La vigilancia tecnológica y la inteligencia competitiva en los estándares de gestión de la calidad en $I+D+i$ ", en Vigo, 2012, pp. 1162-1168.

[12] L. Manderieux, Guía Práctica para la Gestión de Oficinas de Transferencia de Tecnología en Universidades y Centros de Investigación en América Latina. OMPI, Ginebra - Suiza, 2011.

[13] J. Zartha Sossa, A. Avalos Patiño, and S. Aguilar Urrea, "Curvas en S, aplicación en productos innovadores del sector agroindustrial y químico Colombiano", Biotecnol. en el Sector. Agropecu. y Agroindustrial BSAA, vol. 8, n. ${ }^{\circ}$ 2, pp. 95-103, 2010.

[14] M. Delgado Fernández, M. Infante Abreu, Y. Abreu Lee, O. Infante Pérez, J. Díaz Batista, and J. Martínez Moreno, "Vigilancia Tecnológica En Una Universidad De Ciencias Técnicas", Ing. Ind., vol. 32, n. ${ }^{\circ}$ 1, p. 9, 2011.

[15] “The Platform - Open edX”, Open edX, 2019. [Online]. Available: https://open.edx.org/ the-platform/. 